\title{
Is reinfection possible after recovery from COVID-19?
}

Hong Kong Med J 2020;26:264-5

https://doi.org/10.12809/hkmj208601

To the Editor-Recently, some patients have tested positive for severe acute respiratory syndrome coronavirus 2 (SARS-CoV-2) using reverse transcription polymerase chain reaction despite earlier recovery from coronavirus disease 2019 (COVID-19). Among 111 recovered patients, $5 \%$ in China and $10 \%$ in South Korea have tested positive again. ${ }^{1,2}$ Typically, after recovery from a viral infection, the body produces antibodies that can resist reinfection from the same virus. ${ }^{3}$ There is evidence that COVID-19 reinfection is not possible within 7 to 10 days. ${ }^{4}$ A Chinese study on COVID-19 involving primates showed no viral replication in all primary tissue compartments at 5 days postreinfection, indicating that the primary infection of SARS-CoV-2 could prevent subsequent infections. ${ }^{5}$

Positive reverse transcription polymerase chain reaction test results from the patients who have recovered from COVID-19 are possibly attributed to:

(i) The virus persisting within body. Patients with severe acute respiratory syndrome have reported positive results in tests for the virus in faeces 2 months after onset. ${ }^{6}$ Respiratory tract secretion tests have also shown positive results and high concentrations of the virus for 3 weeks after onset. ${ }^{7}$ Virus shedding gradually decreases towards the detection limit around 21 days after onset. ${ }^{8}$

(ii) Cross-contamination from another

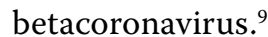

(iii) False positive results. ${ }^{10}$

(iv) Incorrect sample collection methods. The sample may not be collected widely and deeply enough to include the virus, resulting in a negative result. ${ }^{11}$ Furthermore, the virus binds to the angiotensin-converting enzyme 2 receptor and remains in the throat, but the test includes only the upper respiratory tract where the amount of virus has been reduced. ${ }^{12}$ When clinical symptoms are stable, the virus can still spread and infect different organs such as the spleen, hilar lymph nodes, kidneys, liver, and brain; in such cases deep throat saliva test may not be able to detect SARS-CoV-2 infection. ${ }^{13}$

There is currently no supporting evidence for COVID-19 reinfection after recovery. However, it is important to ensure that samples are collected correctly and test procedures are followed properly. In accordance with the advice of the World Health Organization, patients with no clinical symptoms can be discharged from the hospital if they test negative for SARS-CoV-2 infection at least twice after a 24-hour interval. ${ }^{14}$

\section{Author contributions}

All authors contributed to the concept of the study, acquisition and analysis of the data, drafting of the manuscript, and critical revision of the manuscript for important intellectual content. All authors had full access to the data, contributed to the study, approved the final version for publication, and take responsibility for its accuracy and integrity.

\section{Conflicts of interest}

The authors have no conflicts of interest to disclose.

\section{Funding/support}

The authors received no funding source/grants or other materials support for this work.

\section{1,2,3 SK Law, PhD}

${ }^{4}$ Albert WN Leung, PhD

${ }^{1} \mathrm{CXu}$ *, PhD

Key Laboratory of Molecular Target and Clinical Pharmacology, State Key Laboratory of Respiratory Disease, School of Pharmaceutical Sciences \& Fifth Affiliated Hospital, Guangzhou Medical University, Guangzhou, China

2 School of Chinese Medicine, Faculty of Medicine, The Chinese University of Hong Kong, Hong Kong

${ }^{3}$ Department of Science, School of Science and Technology, The Open University of Hong Kong, Hong Kong

${ }^{4}$ Asia-Pacific Institute of Aging Studies, Lingnan University, Hong Kong

*Corresponding author: xcshan@163.com

\section{References}

1. Mystery in Wuhan: Recovered coronavirus patients test negative...then positive. 27 March 2020. Available from: https://www.npr.org/sections/ goatsandsoda/2020/03/27/822407626/mysteryinwuhan-recovered-coronavirus-patients-testnegativethen-positive. Accessed 22 Apr 2020.

2. Over 110 people retest positive for coronavirus: authorities. 12 April 2020. Available from: http://www. koreaherald.com/view.php?ud=20200412000213\&np=3 \&mp=1. Accessed 22 Apr 2020.

3. McCullough KC. Immune response in vitro. In: Delves PJ, Roitt IM, editors. Encyclopedia of Immunology (second edition). London: Academic Press; 1998: 1233-43.

4. Can you be re-infected after recovering from coronavirus? Here's what we know about COVID-19 immunity. 13 April 2020. Available from: https://time.com/5810454/ coronavirus-immunity-reinfection. Accessed 22 Apr 2020.

5. Bao L, Deng W, Gao H, et al. Reinfection could not occur in SARS-CoV-2 infected rhesus macaques. 
BioRxiv [Preprint] 2020. Available from: https://doi. org/10.1101/2020.03.13.990226. Accessed 22 Apr 2020.

6. Isakbaeva ET, Khetsuriani N, Suzanne Beard R, et al. SARS-associated coronavirus transmission, United States. Emerg Infect Dis 2004;10:225-31.

7. Chan JF, Yip CC, To KK, et al. Improved molecular diagnosis of COVID-19 by the novel, highly sensitive and specific COVID-19-RdRp/Hel real-time reverse transcription-PCR assay validated in vitro and with clinical specimens. J Clin Microbiol 2020;58:e00310-20.

8. He X, Lau EH, Wu P, et al. Temporal dynamics in viral shedding and transmissibility of COVID-19. Nat Med 2020 Apr 15. Epub ahead of print.

9. Coronaviridae Study Group of the International Committee on Taxonomy of Viruses. The species severe acute respiratory syndrome-related coronavirus: classifying 2019-nCoV and naming it SARS-CoV-2. Nat Microbiol 2020;5:536-44.
10. Lan L, Xu D, Ye G, et al. Positive RT-PCR test results in patients recovered from COVID-19. JAMA 2020 Feb 27. Epub ahead of print.

11. Yi Y, Lagniton PN, Ye S, Li E, Xu RH. COVID-19: what has been learned and to be learned about the novel coronavirus disease. Int J Biol Sci 2020;16:1753-66.

12. Jia HP, Look DC, Shi L, et al. ACE2 receptor expression and severe acute respiratory syndrome coronavirus infection depend on differentiation of human airway epithelia. J Virol 2005;79:14614-21.

13. Yao XH, Li TY, He ZC, et al. A pathological report of three COVID-19 cases by minimally invasive autopsies [in Chinese]. Zhonghua Bing Li Xue Za Zhi 2020;49:E009.

14. Coronavirus disease (COVID-19) technical guidance: Laboratory testing for 2019-nCoV in humans. 8 April 2020. Available from: https://www.who.int/emergencies/ diseases/novel-coronavirus-2019/technical-guidance/ laboratory-guidance. Accessed 22 Apr 2020. 